\title{
Cathepsin L1
}

National Cancer Institute

\section{Source}

National Cancer Institute. Cathepsin L1. NCI Thesaurus. Code C17277.

Cathepsin L1 (333 aa, $38 \mathrm{kDa}$ ) is encoded by the human CTSL gene. This protein is involved in both proteolysis and immunity. 